Welfare and the State 


\section{WELFARE AND THE STATE}

Who Benefits?

Lois Bryson

Macmillan Education 
ISBN 978-0-333-48826-3 ISBN 978-1-349-22282-7 (eBook)

DOI 10.1007/978-1-349-22282-7

(C) Lois Bryson 1992

Softcover reprint of the hardcover 1st edition 1992

All rights reserved. For information, write:

Scholarly and Reference Division,

St. Martin's Press, Inc., 175 Fifth Avenue,

New York, N.Y. 10010

First published in the United States of America in 1992

ISBN 978-0-312-08054-9

Library of Congress Cataloging-in-Publication Data

Bryson, Lois

Welfare and the State: who benefits? / Lois Bryson.

p. $\mathrm{cm}$.

Includes bibliographical references (p. ) and index.

ISBN 978-0-312-08054-9

1. Public welfare. 2. Social security. 3. Welfare state.

I. Title.

HV31.B75 1992

$361-\mathrm{dc} 20$

92-6861

CIP 


\section{Contents}

List of Tables and Figures

Acknowledgements

viii

Introduction - Who Benefits? 1

1 The Sociological Context 9

A crisis of the welfare state?

Moving in a market-orientated direction $\quad 12$

The political tussle over the welfare state $\quad 15$

$\begin{array}{ll}\text { The global context } & 17\end{array}$

Limits of sociological definitions of welfare 19

Limits of sociological approaches - gender and race $\quad 23$

Broadening the discourse 25

Conclusion $\quad 29$

2 Conventional Welfare Discourses: Their Relevance in the 1990s 30

The duality of the discourse 30

Conventional approaches to defining key terms 33

(i) Social welfare $\quad 33$

(ii) Social policy $\quad 34$

(iii) Social wage $\quad 34$

(iv) Welfare state 36

Data collection and the scope of definitions 36

Normative/political classifications of welfare discourses 39 Classifying perspectives 42

(i) Individualist/anti-collectivist discourses 43

(ii) Social reformist perspectives $\quad 45$

(iii) Political economic perspectives 46 
(iv) Feminist perspectives

(v) Anti-racist perspectives 49

Limits of the perspectives $\quad 52$

Revisiting basic issues $\quad 55$

(i) Residual versus institutional welfare $\quad 55$

(ii) Absolute versus relative poverty 57

(iii) Selective versus universal provision 59

(iv) Horizontal versus vertical equity 63

Welfare and citizenship $\quad 65$

Conclusion $\quad 67$

3 Cross-national Trends in Welfare State Development 69

Broad national approaches to welfare $\quad 70$

The British welfare state - from Poor Laws to the

New Right

The Australian experience - a wage earners'

welfare state

The USA - the traditional laggard 99

Japan - welfare state or welfare society? 106

The Nordic countries - model welfare states $\quad 110$

Conclusion 119

4 The Distribution of State Welfare 121

I. Who benefits from social welfare? 124

Social security 124

Health and other services $\quad 125$

Housing 126

Education $\quad 128$

The better-off and social welfare:

II. Who benefits from occupational welfare? 131

Occupational welfare and the political context 131

The extent of occupational welfare 133

Occupation and social security 134

Occupation and private pensions 135

Other forms of occupational welfare 139

III. Who benefits from fiscal welfare? 143

Defining fiscal welfare $\quad 143$

Levying taxation 143

Progressivity in the tax system 145

Tax exemptions/expenditure 146 
Defining income for taxation purposes $\quad 148$

Opportunities for tax exemptions 149

Housing and taxation 151

Tax allowances for dependants $\quad 152$

Deductibility of gifts to charitable organisations 153

IV. Who benefits from government intervention? 154

5 Men's Welfare State $\quad 159$

Liberal theory and the patriarchal welfare state $\quad 161$

Men and social welfare 164

The family wage 167

Male workers and the usurpation of advantage $\quad 170$

Men and state power $\quad 175$

Men and caring $\quad 177$

Corporatism and citizenship $\quad 180$

Welfare and the role of the state 185

$\begin{array}{ll}\text { Conclusion } & 188\end{array}$

6 Women's Welfare State 190

Women's economic position $\quad 192$

Women's role - from legitimate dependence to

proletarianisation? 196

Education and training 200

Women and employment 201

(i) Unemployment 204

(ii) Relative economic disadvantages of women's employment 205

Child care $\quad 207$

Women and caring 211

Women and power in the welfare state 215

Equality policies $\quad 217$

Threats to recent gains $\quad 222$

Conclusion 223

Conclusion: The Welfare State in the Twenty-first

Century 226

Recommended Reading 235

References 236

Index 253 


\section{List of Tables and Figures}

\section{Tables}

3.1 Government receipts as a percentage of Gross Domestic Product - 1984 or 1985

4.1 Non-wage labour costs as a percentage of wages and salaries, 1978

5.1 Women's dependency in Sweden and the USA 174

6.1 Women's economic dependency in several Western societies

6.2 Forgone total earnings at age 60 from different education and child-bearing scenarios

\section{Figure}

5.1 Gender-structuring of state apparatus 


\section{Acknowledgements}

Many people have provided assistance, support and inspiration during the process of the writing of this book. There are too many for it to be practical to thank them all individually. Nonetheless there are some who have made a very direct contribution to the project and I am keen to acknowledge this contribution and express my thanks.

My greatest debt is to Professor Janet Finch, who proposed the writing of this book on a visit to Australia in 1987. Later, during the research phase, she not only provided advice but also the hospitality of her department and her home in Lancaster. She has been unstinting in her assistance.

People in a number of countries helped me as I moved around collecting data and informed opinions. Others acted as researchers at various stages of the project. Still others have undertaken, with admirable good humour, the tedious task of reading drafts. I have been provided with much helpful and insightful comment. In these varying capacities I am indebted too: Sabina Berloge, Julia Brannen, Drude Dahlerup, Anne Edwards, Annette Felahey, Ian Gough, Dulcie Groves, Beatrice Halsaa, Barbara Hobson, Donald Horne, Cathie Jensen-Lee, Wuokko Knocke, Arnlaug Leira, Inge Maerkedahl, Frauke Meyer-Gosau, David Morgan, Martin Mowbray, Ron Parsler, Kathy Ruane, Diane Sainsbury, Peter TaylorGooby, Steve Tomsen, Lorraine Wheeler and Anna Yeatman.

I want also to take the traditional opportunity to express my gratitude to my deceased parents for encouraging my interest in matters political, and to my children, Frances and Matthew, for their supportive attitudes over the years. Finally I want to take the 
$\mathrm{x}$ Acknowledgements

opportunity to thank Geoff Sharp, the teacher who originally fired my interest in critical sociological analysis.

LOIS BRYSON 